\title{
10
}

\section{Toleration of religious discrimination in employment}

Stuart White

\section{Introduction: toleration and equal opportunity}

Two ideas feature prominently in contemporary accounts of the just society. One is the idea of toleration and the related idea of religious freedom. A second is the idea of equal opportunity and, derived from this, the idea that the state should protect its members from discrimination in relation to jobs and other important goods such as education. This chapter explores an apparent tension between these two commitments. In order to advance their goals, religious associations sometimes want to discriminate in employment decisions on grounds that are typically prohibited under antidiscrimination laws. They may wish to discriminate in favour of those with their own religious views or those with certain life styles, or on grounds of gender, sexual orientation, or even race. How should the state respond to this apparent conflict between religious toleration and equal opportunity? To what extent should the state permit religious associations to discriminate in employment? Recent policy developments, such as the British government's promotion of faith-based schooling and the European Union's recent framework directive on equal opportunity in employment, have increased the urgency of this question.

In this chapter, I explore the question in three stages. Firstly, I outline the key 'civil interests' that I take to be at stake in thinking about the issue of employment discrimination. I explain why a concern for these civil interests might plausibly be thought to support a general prohibition of religiously-motivated employment discrimination and, at the same time, some kind of exemption from anti-discrimination law for religious associations. This sets the scene for the rest of my discussion, in which I explore whether it is possible to craft an exemption that protects what is likely to be of most importance to the religious believer but at the same time secures the other civil interests at stake. I argue that the freedom of religious associations to discriminate in employment should be limited by two principles. The first principle, explored in the second section of the chapter, is that the 
discrimination should be on religion-relevant grounds. On the face of it, this may seem an innocuous enough. As we shall see, however, there is substantial controversy as to what kind of religion-relevant grounds the state should admit as permissible grounds for employment discrimination. The second principle, explored in the third section, is that discrimination should apply only to a restricted range of jobs that have, as I put it, a sufficiently central relationship to the religious activities of the association. I discuss the tricky question of how this principle might be operationalised, and I reject the view that the centrality principle is by itself a sufficient limitation on the freedom of religious associations to discriminate in employment. The concluding section of the chapter enters a final caveat to my account of the permissible grounds of employment discrimination by religious associations. ${ }^{1}$

\section{The civil interests at stake}

My discussion of the problem proceeds from a certain liberal conception of political legitimacy. The exercise of state power over individuals is legitimate, I think, when it is exercised in order to ensure the equitable protection of civil interests. Civil interests (a term I borrow from John Locke's Letter Concerning Toleration $)^{2}$ are interests that are at once basic and common to all citizens, notwithstanding their different conceptions of the good life. State power should be exercised for the sake of protecting these shared basic interests, rather than for the sake of promoting a given conception of the good life. Turning to the issue of religiously-motivated employment discrimination that is our specific concern in this chapter, at least three main interests seem to be at stake.

(1) Opportunity. Citizens have a fundamental civil interest in fair access to income, wealth, and jobs. In the case of jobs, I shall understand fair access in meritocratic terms, i.e., as requiring equal consideration for given employment on the basis of suitable, job-relevant qualifications. If someone is ranked lower in job selection than another on grounds other than those to do with genuine occupational qualification, then this civil interest is violated.

(2) Civic virtue. Citizens share an interest in seeing that other citizens share the specifically civic virtues necessary for the healthy functioning of a just society. These virtues centrally include the virtues of toleration of, and respect for, those of different religious (or irreligious) points of view. Social institutions and practices that militate against the cultivation of these virtues jeopardise this civil interest, and are suspect for this reason.

(3) Religious liberty. This encompasses two distinct interests that we will do well to separate. The first is what we might call the citizen's expressive interest. This is her interest in living in authentic accordance with her religious (or irreligious) beliefs, i.e., in living her life as an expression of the 
said beliefs. ${ }^{3}$ The second is what we might call the citizen's deliberative interest. ${ }^{4}$ This is her interest in having the opportunity to endorse her religious beliefs on the basis of informed reflection or deliberation. The correct answer to the question, 'What is the good life?', is hard to see and, since nobody is obviously an infallible judge of the matter, each individual ought to be able to make her own informed judgement about where the truth of the matter lies. In thinking about religious liberty, then, we need to give attention not only to the freedoms that serve expressive interests, but also to those that serve deliberative interests. Sometimes a concern for A's expressive interest may conflict with a concern for B's deliberative interest, and I take it that, in such cases, deliberative interests should be given priority: A should not have the right to substitute her judgement on fundamental questions about the value and meaning of life for that of $B$ (even if $\mathrm{A}$ is B's parent).

The expressive dimension of religious liberty may also conflict, of course, with other important civil interests. In some cases, our concern for other civil interests will properly trump the concern for this aspect of religious liberty. But at the same time I do think that the concern for the free exercise of religion, for the expressive dimension of religious liberty, is (or can be) a matter of legitimate intrinsic concern, and that we should factor this concern into our construction of a theory of justice. We should not think of religious freedom simply as a residual freedom to act as we like for the sake of religion within the bounds of laws that serve the public interest, but as something that should enter into our conception of what the public interest truly is.

Now, given a concern for the civil interests just described, it is not hard to make a good case for a general prohibition on religiously-motivated employment discrimination. For in a society where such discrimination is permitted, and widely practised, there would be serious injury to all three of these key background civil interests. Religiously-motivated employment discrimination by a prejudiced majority, such as that historically practised against Roman Catholics in the shipyards of Northern Ireland, might well violate the opportunity interest of those in religious minorities, by denying members of such minorities jobs for which they are no less, or even more, qualified than majority competitors. Secondly, workplaces constitute important social spaces in which lessons in tolerance and respect for those of different religions are learned. Permitting religiously-motivated employment discrimination therefore risks the informal education in civic virtues that workplaces otherwise provide..$^{5}$ Thirdly, permitting religiously-motivated employment discrimination might endanger the interests connected with religious liberty. Looked at from the perspective of the employer, this may sound odd: after all, if such discrimination is permitted, the employer is more free to shape the workplace in accordance with her religion. But of course we must consider the interests of the employee, or prospective employee, as well as the employer. If employment is conditioned on con- 
formity to a given religion, then, depending on the character of the labour market and the background system of social rights, this threatens to compromise the expressive and deliberative interests of the employee. Individuals who desperately need employment might find themselves pressured to pretend to beliefs they do not have, or to perform actions (for example, bowing to an icon) that contradict their own beliefs. At the very least, their free deliberation about religious matters might be distorted as they seek to adapt their views to those of the employer.

At least some of these considerations motivated the US Congress to outlaw religiously-motivated employment discrimination as part of the 1964 Civil Rights Act. Title VII of this act prohibits employers from discriminating with respect to hiring, discharging, compensation, terms, conditions, or privileges of employment on account of race, colour, religion, sex, and national origin. However, for our purposes it also noteworthy that the Congress incorporated into the law an exemption for religious associations. In its original form, Section 702 of Title VII stipulated that: 'This subchapter [the Title VII prohibition on discrimination in employment described above] shall not apply ... to a religious corporation, association, educational institution or society with respect to the employment of individuals of a particular religion to perform work connected with the carrying on by such corporation ... of its religious activities. ${ }^{6}$

What might motivate such an exemption? In terms of the framework presented here, the concern is presumably with the expressive interests of the religious. The freedom to give expression to one's religious beliefs in one's life typically requires the freedom to associate with like-minded others in expressive activities, and, in the process of associating, to employ people with the right qualities to guide and support the expressive activities of the association. If people lacking the right qualities are somehow imposed on the association, then its activities will cease to be expressive of its members' beliefs. As Brian Barry puts it: 'If you believe that the sacraments have efficacy only if administered by a man, you can scarcely regard the sex of the person administering them as irrelevant. ${ }^{7}$ For this reason, it might be thought that religious associations should be given some power to discriminate in employment in favour of those with what their members regard as the right qualities; and that, to this end, religious associations should be given some degree of exemption from general anti-discrimination laws as these apply to employment. The putative right to discriminate is grounded in a concern for the expressive dimension of religious liberty.

However, we cannot stop the discussion here. We have already acknowledged how religiously-motivated employment discrimination can jeopardise important civil interests. This prompts the question I shall address in the next two sections: Can we frame a right to employment discrimination for religious associations that (a) secures the core expressive interests of the believer, but (b) does not seriously threaten other key civil interests/the key civil interests of other citizens? 


\section{The relevance principle}

The simplest way to protect the believer's expressive interest would be to give religious associations a blanket exemption from anti-discrimination laws in employment. Some argued for this in the Congressional debate surrounding Title VII of the 1964 Civil Rights Act. ${ }^{8}$ But this is surely too permissive. Under a blanket exemption of the proposed kind, religious associations would not have to give any reason for a given act or pattern of discrimination. But if the rationale for giving religious associations a right to discriminate in employment is that this is necessary to protect the integrity of their religious activities, then, in principle, they should be free to discriminate only on grounds that are relevant to this task. In short, they should be free to discriminate only on what we may term religion-relevant grounds. We may refer to this simply as the relevance principle.

First and foremost, religion-relevant grounds include religious belief. In at least one type of case - appointments to the clergy - nobody disputes the legitimacy of conditioning employment on belief. Nobody seriously questions the right of, say, the Methodist Church to condition employment as a minister on being a Methodist. Controversy does begin to arise, however, once we extend the range of personal characteristics that are taken to be religion-relevant grounds for discrimination, and once we move beyond the clergy to consider other types of employment connected with religious associations. I will examine the second issue, which concerns the range of jobs to which the right of discrimination may apply, in the next section. For the remainder of this section I will focus on the question of what other personal characteristics, in addition to religious belief, might reasonably be seen as providing adequate, religion-relevant grounds for discrimination, assuming, for the moment, that we are considering appointments, like those to the clergy, that are uncontroversially integral to the religious activities of the association.

It seems fairly uncontroversial to include life style and behaviour amongst the grounds that can count as religion-relevant reasons for employment discrimination. If one is prospectively employed to propagate a given Church's creed, then it seems reasonable that the Church can take into account the compatibility of one's life style with this creed in deciding whether to hire one. Things get a lot more controversial, however, when we move on to consider whether certain ascriptive characteristics, such as race, gender, and sexual orientation, should be regarded as admissible religion-relevant grounds for employment discrimination. This is where the conflict with liberal norms becomes evident and the right to discriminate more worrying. The Roman Catholic Church, for example, will currently not consider a female applicant for the priesthood. Should religious associations have the freedom to discriminate in employment on the basis of characteristics such as these if and when their respective religions identify these characteristics as relevant to the performance of certain duties? 
One response to this question holds that the right to discriminate on the basis of such characteristics is already entailed by the apparently uncontroversial right to discriminate (at least in the case of appointments to the priesthood and the like) in favour of those who hold the association's beliefs. If, as in the case of the Roman Catholic Church, it is a part of a given Church's established belief system that only men can be priests, then a woman who demands access to the priesthood apparently reveals herself to have unorthodox beliefs; and so, the argument runs, her exclusion from the priesthood is already entailed by the uncontroversial right to restrict the priesthood to orthodox believers.

However, in many religious communities there is some degree of contestation about belief, and, relatedly, about the relative significance of various beliefs in qualifying one to remain a member of the community in good faith. For example, many Roman Catholics, including many who oppose the ordination of women, do not think that the Church's view about women and the priesthood is a matter of fundamental Church doctrine. They thus have no trouble with the idea that a given person might dissent from the currently authoritative view on this issue and still quite meaningfully be a faithful Roman Catholic. In such a case, it is far from obvious that the right to restrict the priesthood to orthodox believers carries with it, automatically, as a definitional matter, the right to exclude those who dissent from the currently authoritative view about the ordination of women, including, of necessity, women who wish to be priests. Pushing this point a little further, consider how things would stand if a Church, like the Roman Catholic Church, did try to defend its exclusion of a woman from the priesthood in the suggested way. Would the Church also fire or refuse to employ as priests men who hold the dissenting view? (There are, after all, many priests in the Roman Catholic Church at present who do hold the dissenting view. $)^{9}$ If the Church does not refuse men entry to the priesthood on these grounds, this indicates that, in the case of male applicants to the priesthood, the Church does not regard a person's holding the dissenting view as sufficient grounds for disqualifying him from the priestly office. So if it then invokes possession of this view as grounds for disqualification in the case of women who wish to be priests, the Church is straightforwardly engaged in gender-based discrimination. It would be holding women, quite arbitrarily, to a different standard of belief than men.

It is by no means clear, then, that the right to discriminate in favour of orthodox believers directly entails the right to discriminate on grounds of gender, even where the authoritative view within the religious association in question is that women cannot hold certain positions.

Moreover, even if the right to discriminate on grounds of gender were directly entailed by the right to discriminate in favour of orthodox believers, the critic might simply argue that in this case the right to discriminate on the basis of belief should be compromised in the interests of securing gender equality. What initially seems an innocuous basis for discrimination is, it 
might be said, quite unacceptable to the extent that, for example, it sanctions women's exclusion from the priesthood.

The argument that the state should not permit religious associations to practice sexual discrimination in employment - even in relation to the clergy - is made by the legal scholar Jane Rutherford. ${ }^{10}$ Rutherford points out that women in conservative religious groups increasingly perceive a terrible choice between exclusion from the priesthood and the exile involved in leaving their original religious community. Moreover, the fear of confronting such a choice might inhibit women believers from exploring their own beliefs. ${ }^{11}$ In the terms of the argument here developed, Rutherford holds that giving religious associations the right to discriminate in employment on the basis of gender (or race), including the case of appointments to the clergy, objectionably burdens the expressive and deliberative interests of those people whose employment options are closed down by the resulting sexual (or racial) discrimination. Religious associations should not be free, she thus concludes, to treat gender (or race) as religion-relevant grounds for employment discrimination. ${ }^{12}$

On the other hand, according to Martha Nussbaum, 'it seems illiberal to hold that practices internal to the conduct of [a] religious body ... [such as] the choice of priests' should be subject to this kind of regulation by the state. ${ }^{13}$ Nussbaum does not say a great deal in support of this claim, but I suspect that she is right to view such regulation as inappropriate. A first point to make in response to Rutherford's position is that the demand to be a priest cannot be divorced from the demand that others acknowledge one's admissibility as a priest in the context of their religious community. However, it does not seem reasonable, as a general matter, to expect others to acknowledge this. What would Rutherford say, for example, in the case of a man demanding the right to undertake priestly functions in a 'Goddess religion' that ordinarily restricts these functions to women? Should the state compel women members of this religious group to admit maverick, but perfectly sincere, men as priests? It hardly seems fair to let such men, no matter how sincere they may be, impose themselves on the religious life of another group of citizens in this way.

But, it might be said, the women worshippers of the 'Goddess' do not manifest patriarchal prejudice when they demand the right to exclude men from their priesthood - indeed, they may trying to create a space in which women can recover from patriarchy - and this is the crucial difference between them and religious groups that wish to exclude women from the priesthood. The state should not pander to sexist prejudice, and since women's exclusion from the clergy necessarily reflects sexist prejudice, the state should not indulge religious groups that wish to practise such exclusion. It may, however, permit women-centred religious groups that exclude men from the priesthood because such groups may serve to help society recover from its legacy of patriarchy. The problem with this argument, however, is that it is in fact quite wrong - and quite prejudiced - to assume 
that the desire for an all-male priesthood manifests sexist prejudice. Such a view rests on a rather uninformed, simplistic appreciation of what may be going on in citizens' religious lives.

Consider the case of James, a 'theologically liberal Odinist'. James believes that there is a divine force in the universe and that we ought to try to live in ways that embody the qualities of this force. James believes that this divine force is represented symbolically in different ways in different religious traditions. There is, he thinks, no single representation that captures perfectly the essence of the divine force, but some representations are better for some people, given their situation and needs. Thus, he can quite understand why some women (or, indeed, men) find it imperative to imagine the divine force using feminine imagery, and why, accordingly, they would wish to restrict priestly functions within their religious groups to women. From time to time, he finds it helpful to participate in the rituals of such groups. But James has recently read Robert Bly's Iron John, and now believes that for him, and for some other people, it is better, at least for a period, to work primarily in a religious tradition that pictures the divine force largely in male terms. Specifically, he wishes to participate in a neoOdinist group that pictures the divine force using figures from Norse mythology, and in which priestly functions are carried out by men. Perhaps James suffers from timidity, and he feels that he will overcome this, and so live a life more worthy of the divine force, by participating in a religious tradition that gives emphasis to the virtues of 'manly courage'. Other people may wish to focus on cultivating other qualities of the divine; or they may find other representations effective in cultivating the quality he is currently most interested in; and so, in James's view, they may find that other religious groups, with other representations of the divine, are more appropriate to them. But for him, as things stand, and for the time being, this form of neo-Odinism is, in his view, the appropriate group to join and participate in. ${ }^{14}$

Now, so described, James surely cannot be considered a sexist. His desire to worship in a religious community in which priestly functions are restricted to men does not reflect a view that women are inferior to, or less close to God than, men. It reflects a judgement as to what kind of symbolic framework is likely to be most effective in advancing the ethical project that he sees as central to his life, and there is nothing intrinsically sexist about this project in itself. ${ }^{15}$ Now to say that the state should not permit religious groups to restrict priestly functions to men is to deny people like James the freedom to form and join religious groups that they judge most effective to advancing wholly non-sexist, and, otherwise, intrinsically decent, even admirable, personal projects. Perhaps there is some indirect consequence of allowing such groups that is so bad, in terms of the background civil interests, as to justify restricting the apparently unobjectionable freedom of James to form and join such groups. But what now seems wholly implausible is the claim that the state is justified in denying James this freedom on 
the grounds that all-male priesthoods are intrinsically sexist and (therefore) objectionable. With cases like that of James in mind, I am inclined to agree with the basic spirit of what Martha Nussbaum says when she writes that 'The choices of adult citizens to remain in a religious body that refuses to hire women as priests should ... be respected as a part of what we agree to respect when we acknowledge that our society contains a plurality of reasonable comprehensive conceptions of the good. ${ }^{, 16}$

Nothing I have said is meant to deny the reality of the agonising choices that many women in traditional religious communities face today as a result of their exclusion from the priesthood. But I would contend that this 'fact of agonising choice' cannot be a decisive objection to the practice of exclusion, for the simple reason that no coherent regime of religious liberty can protect people from this kind of choice. The decision to belong to a given religious community necessarily carries with it an acceptance of some immediate restrictions on the beliefs one has and acts from. If, on continued reflection, one's beliefs evolve, one cannot claim the right to remain a full member of this community, expecting it to accommodate one's new beliefs as one would like. Such an idea verges on incoherence: unless all believers change their beliefs in exactly the same way, at the same time, a right of the suggested kind could not be generalised to all members of a given religious community without generating claims for accommodation that contradict each other. The individual's expressive interest is protected by her having the freedom to exit from a faith community when her beliefs evolve away from the mainstream of the community and to join with like-minded others in new associations; not, as Rutherford implies, in having the freedom to avoid exiting, and to insist on accommodation when this happens.

\section{The centrality principle}

I tentatively conclude, then, that religious associations should be free to discriminate in employment on religion-relevant grounds, where these grounds include belief, life style and behaviour, and even ascriptive characteristics such as gender and race where there is an authoritative view within a given religious association that such characteristics are in some way relevant to the performance of certain ecclesiastical duties. ${ }^{17}$

By itself, however, the relevance principle does not place anything like a sufficient limit on the freedom of religious associations to discriminate in employment. To see why it is insufficient, consider another court case from the US, the notorious case of Corporation of the Presiding Bishop of the Church of Latter Day Saints v. Amos. ${ }^{18}$ In the Amos case, a janitor, Arthur Mayson, who had been employed for sixteen years at a Mormon-run nonprofit gymnasium open to the general public, was fired for not complying with the eligibility test for attendance at Mormon temples. He sued the Mormon Church for unfair dismissal, and won the case in the district 
court, only to have the district court decision overturned by the Supreme Court. ${ }^{19}$ Amos is a clear case of discrimination on religion-relevant grounds as defined above: Mayson was fired because his life style was not compatible with Mormon beliefs. And yet it seems important that Mayson was, after all, a janitor, not a priest or a minister. Moreover, he was a janitor not in a church, but in a gym; and in a gym that wasn't even exclusive to Mormon users. Though an employee of the Mormon Church, the nature of his employment was clearly very remote from the activities that are central to the religious life of the Mormon Church, and the employment of non-believers and the like in positions so distant from these activities hardly represents a credible threat to the expressive interests of individual Mormons. No individual Mormon is going to find her ability to live in authentic accordance with Mormon precepts vitiated because a public gymnasium owned by her Church employs a janitor who has, outside working hours, a somewhat racy life style.

At the same time, granting religious associations a right to employment discrimination across the full range of jobs they control could well pose a serious threat to the background civil interests described above: opportunity, civic virtue, and religious liberty (the expressive and deliberative interests of actual and prospective employees). As Nancy Rosenblum and Brian Barry both point out, the Supreme Court's decision in Amos displayed an extreme preoccupation with possible threats to the liberty of religious associations, but no concern at all with the threats to the religious freedom of individuals like Mason who stand vulnerable in the face of the economic power of such associations. ${ }^{20}$ The threat to background civil interests may not be that great where religious associations control access to a relatively small proportion of a society's employment. But the economic power, and control over employment, wielded by religious associations can actually be quite considerable. Sticking with the Mormons, for example, Nancy Rosenblum points out that: 'Among its commercial assets, the Mormon Church owns the top beef ranch in the world, the largest producer of nuts in America, the country's fourteenth-largest radio chain, and the Beneficial Life Insurance Company, with assets of $\$ 1.6$ billion. ${ }^{21}$ Proposals in the USA and Britain for 'faith-based' social policy, using public subsidies to extend the role of Churches in the provision of social welfare, raise similar anxieties about the potential for religiously-motivated employment discrimination that violates important civil interests. In view of this threat, it seems appropriate to limit quite sharply the range of employment within which religious associations may be permitted to discriminate. The challenge we then face, of course, is how to define this limit. Focusing on what seems amiss in the Amos case, we might say that the right to discriminate may apply only to jobs that have a sufficiently central relationship to the religious activities of a religious association. We may refer to this as the centrality principle. $^{22}$ 
As I have just stated it, however, the centrality principle is too abstract to be of much use. Clearly, we need to say more about how the state is to judge whether jobs have 'a sufficiently central relationship to the religious activities of a religious association' and about the sort of things it should look for in making such a judgement. So far as I can see, there are two basic approaches we might take here, neither of which is free of difficulty.

A first approach might be described as objectivist, because it involves constructing a public definition of what can count as the core, religious activity of a religious association, and then using this definition as an objective standard by which to assess any given association's claims that specific jobs should be covered by the right to discriminate. The approach might be developed along the following lines. First, we try to define a category of activity that is essentially religious: activity the meaning and purpose of which is necessarily religious, so that to speak of engaging in such activity outside a context of religious meaning and purpose is nonsensical. Participation in a ritual of worship, for example, is an activity that is essentially religious. ${ }^{23}$ Other practices that arguably fall within the category of the essentially religious include: evangelism (bearing witness to religious ideas, spreading the 'good news'); spiritual guidance (advising fellow believers on how to live in accordance their religious beliefs); and religious education (teaching the faith, involving a combination of evangelism and guidance). These activities are at the core of our understanding of what a religious association does. Obviously, not all activities are essentially religious. One might, for example, seek to make a profit for its own sake, not because one thinks that doing so is the best way to serve the Lord; one might give to a charity out of brute sympathy for the victims of some disaster or injustice, not because of any religious belief. However, we can perhaps define a second category of mission activity. A practice is mission activity, as I here use the term, if the practice is not essentially religious, but if, for those engaged in it, it has a primary meaning and purpose that is religious. For example, providing hot food on a cold winter's night for the homeless might be a form of mission activity for members of a given religious group.

We might now say: the right to employment discrimination held by religious associations ought to extend to jobs that are integral to the essentially religious activity of the association. Appointments to the clergy most obviously fall into this category. But other kinds of employment, for example, as a church organist, also plausibly fall into this category. In this sphere of employment, concern for the expressive interest of the believer grounds a very strong presumption in favour of permitting employment discrimination. Beyond this publicly-defined sphere of essentially religious activity, as we move into the realm of what I have termed mission activity, some freedom to discriminate, on religion-relevant grounds, may be permissible. But the presumption in favour of this freedom in this area is weaker, and may well be outweighed by a concern to prevent religious asso- 
ciations exercising too much control over a given type of employment (for example, in the health-care and education sectors).

The objection to this method of implementing the centrality principle is that the attempt to construct a public definition of protected, essentially religious activity will probably conflict with the self-understandings of some religious groups. A given Church might well regard aspects of its mission activity, in the sense defined above, as no less an important expression of its beliefs than activities, such as worship, that the state defines as essentially religious. Indeed, the very distinction between worship and, say, commercial activity, is a distinction that some religious groups will not accept: on some religious views, making a profit - for the Lord - is itself a form of worship. So some religious groups stand to be much more heavily burdened by this approach, by the distinctions it draws, than others.

An alternative approach, which seems to avoid this objection, is subjectivist. In this approach, the kind of work that counts as central to the religious activity of a given religious association depends simply on what activities its members view as such. If the right of their Church to discriminate in relation to a given job is disputed, then the state requires the Church to show that its members generally regard the activity with which the job is concerned as central to the Church's religious activities. ${ }^{24}$ However, while this approach would be more neutral in its impact on different religious groups, it would presumably result in religious associations' having freedom to discriminate over a somewhat wider range of jobs. In effect, it would extend this freedom to include broad swathes of jobs that concern what I referred to above as mission activity. But as I have just noted, such an extension carries the risk of greater injury to background civil interests. If we are to balance these civil interests fairly against the expressive interests of believers, we may find it necessary to develop some standard, or standards, against which we can assess the degree of priority we should give to believers' expressive interests. This, however, points us directly back in the objectivist direction, in which public criteria of centrality are articulated and then used as an external standard against which to judge specific groups' demands for discrimination. I suspect, then, that some nonneutrality of impact between religious groups is the price we have to pay to ensure the fairest overall treatment of the various civil interests at stake.

Some commentators, such as Bruce Bagni, argue that all the state need and should do in this area is condition the right to discriminate on some version of the centrality principle. ${ }^{25}$ Bagni believes that we can define a 'spiritual epicentre' to the activity of religious associations (along objectivist lines), and that religious associations should then be given complete immunity from anti-discrimination laws as regards employment that has 'epicentral attributes'. Outside the epicentre, these laws should apply. This accords with the position adopted by US courts in disputes concerning appointments to the clergy. For example, in the case of Simpson v. Wells Lamont Corporation, ${ }^{26}$ an individual claimed he had been fired from his 
position as minister in a church in part because of the colour of his wife. The local court refused to hear his case, arguing that appointments to the ministry are properly the concern of the relevant church alone: 'who will preach from the pulpit, and who will occupy the church parsonage', the court claimed, is a concern beyond the proper remit of a civil (as opposed to an ecclesiastical) court.

Jane Rutherford is critical of this practice, and I think she is right to be so. Rutherford cites the case of Darreyl M. Young, who, despite 'glowing reports' on her work, was sacked from her job as a minister with the United Methodist Church. Young claimed she was the victim of sexual and racial discrimination. As Rutherford puts it: 'If Young had worked for any other employer, the government would have assured her an opportunity to present her case of sex and race discrimination to a federal court. However, the district court dismissed the case on the basis of the Religion Clauses of the First Amendment before Young even had a chance to present the facts. ${ }^{27}$ It is hard to see why employees of religious associations, even those working in what Bagni would call the 'spiritual epicentre' of these associations, ought to be left so vulnerable to the arbitrary exercise of institutional power. On the one hand, I do not see how it would significantly burden the expressive interest of association members to insist that their association explain, in a court of law or relevant employment tribunal, the religious grounds for a disputed employment decision, even where the decision relates to epicentral employment. ${ }^{28}$ On the other hand, the vulnerability that stems from exposure to unaccountable power could well threaten employees' expressive (and also, perhaps, deliberative) interests. Even if the employee is never actually victimised by such power, her freedom is reduced by the position of dependency and vulnerability this creates. ${ }^{29}$ Those so dependent might readily become wrapped up in the game of pandering to those who hold arbitrary power over them, and this might easily encourage a superficial, inauthentic engagement with higher matters of the spirit.

\section{Conclusion and caveat}

For this reason, at least, I think the centrality principle should be combined with the relevance principle. Religious associations should be free to discriminate in employment, therefore, only on religion-relevant grounds, and only for jobs that have a sufficiently central relationship to their religious activities. I have argued that the relevance principle should be understood to admit gender and other ascriptive characteristics as permissible grounds for discrimination. I have sketched two ways in which the centrality principle might be operationalised, and I have argued that we probably strike the best, fairest balance between the various civil interests at stake if the state judges claims to centrality by reference to a public, external standard such as, perhaps, a public definition of 'essentially religious' employment. 
In closing I would like to enter a final caveat concerning my defence of the right of religious groups to treat characteristics like gender as religionrelevant grounds for discrimination in appointments to the priesthood. One further objection to this practice, not considered above, appeals to the civil interest in civic virtue. In a just society, a key element of civic virtue is the disposition to respect other citizens, qua citizens, as equals: the disposition to wish to see them enjoy equal civil and political rights and economic opportunity. And it might be objected that exclusion from the priesthood sends a powerful symbolic message of women's supposed inferiority that undermines equal respect for women in the wider political community. ${ }^{30}$ Now, were this the case, and were it also the case that there is no other effective way of undoing the harm in question, then I accept that the freedom of religious groups to exclude women from the priesthood would need to be reconsidered. Nevertheless, I think we should treat this sort of argument with great caution. It is all too easy to speculate that a given practice has undesirable wider effects on our public culture. Before we proceed to take away the freedom of citizens to engage in any such practice, however, we should have sound evidence that the alleged effects are genuine. Moreover, we have seen above that there is nothing intrinsically sexist about a desire to form and/or join a religious group with a clergy exclusive to one gender. In some cases, this desire may be tied to perfectly decent, even admirable, personal projects. Consequently, even if we did have sound evidence that exclusion of women from the clergy of religious groups is harming women's standing in the wider political community, we would need to balance this harm against the harm we would do, in prohibiting such groups, to non-sexist men (and perhaps women) innocently seeking to form and join groups of this kind. As in other cases of disputed toleration, where similar harms are alleged, such as the dispute over pornography, a concern to protect intrinsically legitimate and valuable personal freedoms should incline us to look first to alternative remedies for the alleged harms, before we legislate to remove the freedoms. ${ }^{31}$

\section{Notes}

I would like to thank Chris Bertram, Selina Chen, Jurgen DeWispelaere, Peter Edge, Cecile Fabre, Diana Gardner, Paul Kelly, Steven Lukes, David Miller, Tariq Modood, Julian Rivers, Nancy Rosenblum, Gijs van Donselaar, and Katherine Wedell for comments on earlier versions of this chapter and/or on the topic it concerns.

1 I should perhaps note that while my focus will be on religious associations, this does not reflect a judgement that the issue I discuss pertains only to religious associations. Parallel issues arise, I think, in the case of political associations, such as political parties, and I do not mean to imply that they should not have equivalent or analogous freedoms.

2 See J. Locke, 'A letter concerning toleration', trans W. Popple, in D. Wootton (ed.), Locke's Political Writings (Harmondsworth: Penguin, 1993 [1689]), pp. 390-436. I do not claim that my use of the term, or my approach to the central question of this chapter, are such as Locke would approve of. 
3 I take the term from J. Cohen, 'Freedom of expression', in D. Heyd, Toleration: An Elusive Virtue (Princeton, NJ: Princeton University Press, 1996), pp. 173-225, at pp. 185-7, though I should add that Cohen uses the term strictly to refer to the citizen's interest in articulating viewpoints and the like, whereas I am using the term in a way that encompasses a broader range of activities that can be said to be expressive of a given conception of the good. See also R. Dworkin, Sovereign Virtue: The Theory and Practice of Equality (Cambridge, MA: Harvard University Press, 2000), pp. 270-4.

4 Again, see Cohen, 'Freedom of expression', at p. 188.

5 See N. Rosenblum, 'Amos: religious autonomy and the moral uses of pluralism', in N. Rosenblum (ed.), Obligations of Citizenship and the Demands of Faith: Religious Accommodation in Pluralist Democracies (Princeton, NJ: Princeton University Press, 2000), pp. 165-95, at p. 166.

6 Congress amended the exemption in 1972, deleting the word 'religious' in the final clause. In addition to the exemption carved out in Congressional legislation, US courts have repeatedly ruled that, under the free exercise clause of the First Amendment, religious associations have a more or less unlimited right to discriminate in relation to the employment of clergy.

7 B. Barry, Culture and Equality (Oxford: Polity, 2000), p. 174.

8 As one Senator Ervin put it: 'For the life of me, I cannot comprehend why the EEOC [Equal Employment Opportunity Commission] and why those who are championing this cause [anti-discrimination] are so greedy for power that they want to lay the political hands of Caesar on the employment practices of churches of God' (cited in Rosenblum, 'Amos', p. 170).

9 See, for example, the 'Radical Catholic' website at: www.bway.net/ halsall/radcath.html

10 See J. Rutherford, 'Equality as the primary constitutional value: the case for applying employment discrimination laws to religion', Cornell Law Review, 81 (1996) 1049-128.

11 Rutherford, ibid., p. 1085.

12 Rutherford would allow Churches to pay damages to women who are excluded from the priesthood instead of admitting women to the priesthood. But the financial implications of this could obviously have the same effect as a direct insistence to admit women.

13 M. Nussbaum, 'A plea for difficulty', in S. M. Okin et al., Is Multiculturalism Bad for Women? (Princeton, NJ: Princeton University Press, 1999), pp. 105-14, at p. 114.

14 I confess that this example is based somewhat on my own speculative imaginings as to what contemporary Odinists believe and do. Nothing of substance in my argument actually hangs on James's desired religious group being specifically 'Odinist', and I apologise to any contemporary Odinists who feel this example misrepresents their religion. I am confident, however, that this hypothetical example is perfectly realistic in its essentials.

15 The project is to live in accordance with the qualities of the divine force, and James does not think this force is ultimately male or female, or that the totality of its qualities are in some sense more male than female.

16 Nussbaum, 'Plea for difficulty', p. 114. This conclusion also seems consistent with what John Rawls says about the relationship between 'principles of political justice' and associational life: '. . . liberal principles of political justice do not require ecclesiastical governance to be democratic...nor need the benefits 
attached to a church's hierarchy of offices satisfy a specified distributive principle... the principles of political justice do not apply to the internal life of the church, nor is it desirable, or consistent with liberty of conscience of freedom of association, that they should' (italics added). See J. Rawls, 'The idea of public reason revisited', in J. Rawls, The Law of Peoples (Cambridge, MA: Harvard University Press, 1999), pp. 129-80, at p. 158.

17 I have explicitly considered only the case of sexual discrimination for the priesthood, but I believe similar considerations to those advanced above would also allow for racial discrimination where this has a basis in the religious association's belief system.

18 Corporation of the Presiding Bishop of the Church of Latter Day Saints v. Amos (483 U.S. 327 [1987]).

19 The Supreme Court did not determine that religious associations have a right to discriminate of this kind guaranteed by the US constitution (as part of the right of 'free exercise' of religion guaranteed under the First Amendment). The right to discriminate is based on the exemption to anti-discrimination laws that Congress granted (specifically, the Section 702 exemption to Title VII of the 1964 Civil Rights Act, as amended by Congress in 1972), and the Supreme Court held that this Congressionally crafted exemption was not unconstitutional.

20 See Rosenblum, 'Amos', pp. 183-7, and Barry, Culture and Equality, p. 167.

21 See Rosenblum, 'Amos', p. 186.

22 The European Union's recent anti-discrimination framework directive seems to be groping at such a principle when it says that discrimination on grounds of religion by religious associations is admitted specifically 'for the particular occupational activities within those organizations which are directly and essentially related to religion or belief', and where 'the nature of these activities or the context in which they are carried out' are such that 'a person's religion or belief constitute a genuine occupational requirement.' See Article 4, Council Directive establishing a general framework for equal treatment in employment and occupation (presented by the Commission pursuant to Article 250 (2) of the EC-Treaty), available at:

http://europa.eu.int/eur-lex/en/com/dat/2000/en_500PC0652.html.

23 Perhaps, it would be more exact to say that an essentially religious activity is one the context of which necessarily includes the religious. For a given worshipper, the activity of worship could have other meanings and purposes, to do for example with friendship and social life. But if someone attends rituals of worship only for these non-religious reasons, I would question whether what they are doing is in fact worship.

24 This version of the centrality principle is suggested by Nancy Rosenblum in her discussion of the Supreme Court's arguments in Amos. See 'Amos', pp. 174-6.

25 See B. Bagni, 'Discrimination in the name of the Lord: a critical evaluation of discrimination by religious organizations', Columbia Law Review, 79 (1979) 1514-49.

26 Simpson v. Wells Lamont Corporation (494 F2d 490 (5th Cir. 1974)). See Bagni, 'Discrimination', p. 1535; Rosenblum, 'Amos', p. 169.

27 Rutherford, 'Equality', pp. 1056-7.

28 Or to explain legitimate, non-religious grounds for a decision, for instance neglect of duties. It might be said that we should not insist on bringing Church 
employees into state tribunals if we are satisfied that the Church itself has sufficiently fair internal appeals processes. But could we be sure these processes would be sufficiently fair and impartial? Note that even if a state tribunal finds against a Church in such a case, this need not entail Church members being lumbered with a cleric they do not want. The Church can be required to pay compensation instead.

29 See P. Pettit, Republicanism: A Theory of Freedom and Government (Oxford: Oxford University Press, 1997); and Q. Skinner, Liberty Before Liberalism (Cambridge: Cambridge University Press, 1998).

30 This point also features in Rutherford's argument against permitting sexual discrimination in employment, including appointments to the priesthood. See Rutherford, 'Equality', pp. 1087-9.

31 See Cohen, 'Freedom of expression', especially pp. 198-9. 